\title{
Improving the Pedagogical Conditions of Preparing Students for Sports Competitions
}

\section{Sansizbay KadirniyazovichSaparniyazov}

Independent researcher of the Karakalpak branch of the Uzbek Research Institute of Pedagogical Sciences named after T.N.Qori-Niyazi, Uzbekistan.

\section{Article History: Received: 11 January 2021; Accepted: 27 February 2021; Published online: 5 April 2021}

\begin{abstract}
Relevance. Sports competitions are one of the most effective forms of organizing mass health-improving and sports work. Competitions act not only as a form, but also as a means of enhancing the general physical, sports-applied and sports training of students.

Aim. This article is written about improving the pedagogical conditions for preparing students for sports competitions.

Methods. In this article were used methods of analysis of scientific and methodological literature on the research topic; study of educational and normative documentation, state educational standard and curriculum; study of programs and curriculum thematic plans, work experience of institutions of additional education; analysis of the results of the activities of teacherstrainers and students of the Faculty of Physical Education; ascertaining experiment; pedagogical observation; individual conversations with participants in the educational process; pedagogical experiment; mathematical and statistical methods of data processing, etc.

Results. The types of competence, researches of scientists on the chosen topic are analyzed.

Conclusion. Conclusions are given about the forms, methods and means for the improvement of pedagogical conditions for preparing students for sports competitions.
\end{abstract}

Keywords: physical education, sports competitions, pedagogical conditions, students.

\section{Introduction}

The modern practice of teaching, training and retraining of personnel for various sectors of the country's economy requires constant creative improvement of the teaching staff of higher educational institutions, providing a solution to this educational problem. This, in turn, makes new demands on the structure and content, pedagogical conditions of education in various educational institutions of physical culture and sports infrastructure.

Physical culture is a part of the culture of society, the defining aspect of which is the spiritual function of a person, associated with development:

- thinking;

- imagination;

- emotions;

- creation.

Also, general cultural functions include: upbringing, education and health through physical education. Sport develops in a person: will, hard work, courage, honesty, the development of humanistic confidence, respect for the enemy, social activity, patriotism, honor, dedication to one's cause.

The educational process of sports subjects includes:

- new types of movements are being studied;

- special literature is read;

- training videos are watched;

- certificates of teachers and judges are obtained;

- in-depth study of selected activities, etc.

Physical education and sports are part of a health care system that helps prevent and reduce illness, rehabilitate people with physical injuries, help them return to sports and work, increase life expectancy, and satisfy people with active recreation.

Sports competitions are one of the most effective forms of organizing mass health-improving and sports work. Competitions act not only as a form, but also as a means of enhancing the general physical, sports-applied and sports training of students. Sports results are, in essence, an integrative indicator of the quality and effectiveness of a student's psychophysical training, carried out in training sessions. Under the conditions of competition, students more fully demonstrate their physical capabilities. That is why the acceptance of standards for general physical training in training sessions is carried out in a competitive environment at test competitions in a training group or in a training stream. Thus, sports competitions can act both as a means of training and as a method of monitoring the effectiveness of the educational and training process.

\section{Materials and methods}

Research methods:

- $\quad$ analysis of scientific and methodological literature on the research topic; 
- $\quad$ study of educational - normative documentation, state educational standard and curriculum;

- $\quad$ study of programs and educational - thematic plans, experience of work of institutions of additional education;

- $\quad$ analysis of the results of the activities of teachers-trainers and students of the Faculty of Physical Education;

- $\quad$ ascertaining experiment;

- $\quad$ pedagogical supervision;

- $\quad$ individual conversations with participants in the educational process; pedagogical experiment.

- mathematical and statistical methods of data processing, etc.

\section{Literature survey}

When studying at a university, basic professional qualities are laid, professional abilities are developed, which is a necessary condition for successfully mastering a profession, for preparing sports competitions. Preparation of a student for sports competitions is understood as such a psychological and pedagogical state of the student's personality, which arises as a result of resolving the contradiction between the desired and the actual in the individual's own health and encourages him to improve himself in the valeological aspect.

This is especially important when preparing a student for sports competitions during physical education classes. It is the future athletes who must not only self-strengthen, self-preserve and self-cultivate a culture of health, but also apply their knowledge and skills in their future professional activities. And for this it is necessary to provide classes with the necessary pedagogical conditions that make the process more effective. Therefore, the problem of improving the improvement of pedagogical conditions for preparing students for sports competitions is relevant at this stage of the development of pedagogical education.

A large number of studies have been devoted to the issues of improving the pedagogical conditions of preparing students for sports competitions in the psychological and pedagogical literature.

1) A modern approach to considering topical issues of improving the professional training of teaching staff: Abdalina L.V. [1], Frolova O.S. [1], Il'ina N.F. [5], Isyanov R. [6], Rustamov K. [6], Rustamova, N. [6, 19, 20, 27], Lavitskaya, E. S. [11], Senko Yu.V. [21], Shkerina L.V. [22], Zvyagintseva, N. Yu. [28] and others.

2) Different aspects of professional training of future physical culture teachers: Abramova V.V. [2], Bagautdinov Z.M. [3], Kal'kova G.V. [7], KholodovZh.K. [8], Litvintseva, I.G. [13], Makarov, P. A. [14], Moskvitina, L.N. [15], Rakhimov, B. K., Misirova, N. T., Norboeva, S. M., Toshmatova, M. D., Turdieva, R. K. [17], Tikhomirov, Yu. V., Pravdov, M. A. [24] and others.

3) Preparing students for sports competitions: Korshunova, O. S. [10], Lavitskaya, E. S. [12], Butin I.M. [4], Verevkina S.V., Sapegina T.A. [25], Nurmagomedova E.N. [26], Bal'sevich, V.K. [29], Panachev, V.D. [30], Treshcheva, O.L. [31] and others.

The purpose of these studies was mainly focused on the study of the regularities of the formation of professional readiness of students of physical culture faculties in the process of studying at a university, arising from contradictions and the conditions for their resolution.

\section{Discussion}

An important link in the professional training of students for sports competitions is the improvement of the pedagogical process in general and in the disciplines of physical culture and sports in particular.

The entire system of student sports competitions is built on the basis of the principle "from simple to complex", i.e. from intra-university credit competitions in a study group, on a course (often according to simplified rules) to inter-university, etc. before international student competitions.

Intra-university sports competitions include credit competitions within study groups, educational streams on a course, competitions between courses of faculties, between faculties. Depending on the content of the "Regulations on the competition", the competition can be either personal (for each speaker), or team, or personal-team; accessible to every student, or for the "sports elite" of the study group, course, faculty, determined at the preliminary competitive stages. But in any case, every student can participate in the first stages of this system of intra-university competitions, regardless of the level of his sports readiness.

Intra-university competitions in sports (including mass crosses, relay races, etc.):

- crediting competitions in training sessions;

- competitions for the championship of study groups;

- competitions for the championship of the courses;

- competitions for the championship of faculties (competitions for the championship of dormitories);

- competitions for the championship of the university.

Intercollegiate sports competitions or complex sports events:

- friendly competitions between courses, faculties, universities;

- district, city competitions;

- regional competitions; 
- zonal competitions (on a territorial or departmental basis);

- national student competitions and participation in national teams in national competitions.

International sports competitions for students:

- friendly competitions between individual faculties or universities;

- championships and Universiades;

- participation in the national teams of the country in the championships of Asia, Europe, the World and the Olympic Games.

In interuniversity competitions, the strongest student-athletes usually participate and compete either personally or as part of national teams of individual courses, faculties, and a university.

The target objectives of interuniversity competitions, as well as their sports level, can be very different: for example, friendly sports meetings between students of the same faculties of different universities or between teams of one-profile educational institutions. The purpose of such competitions is rather to establish personal contacts between future colleagues in the profession than to find out a sports advantage. However, a sports task can also be set - to achieve the best sports result in competitions between universities of a city, district or universities of the country. This determines the level of sports readiness of students of each university, and, consequently, the nature of the attitude in individual educational institutions to the sports interests of students and to the creation of the necessary conditions for the sports improvement of student athletes.

At the level of individual universities, on the initiative of the administration and public organizations, international sports meetings can be organized. International student competitions are also organized by interuniversity public sports associations.

\section{The process of preparing students for sports competitions}

As you know, the success of the competition results directly depends on the coaching work: the chosen means of physical and psychological training of young athletes. The breadth of horizons, the level of knowledge, professional experience, the ability to unite a team, erudition in the psychology of athletes, exactingness, consistency and adherence to principles in work - this is not a complete list of qualities that a coach should have. It is a mistake to believe that preparing students for competition is about identifying the strongest. The most important indicator of high-quality trainings with young athletes is the systematic improvement of sportsmanship, control of the growth of the emotional and physiological background, as well as the functional capabilities of the body. At the same time, the improvement process should take place taking into account the individual characteristics of each student.

In addition to the development of physical fitness and technical mastery of a certain kind of sport, tactical training plays an important role in the training of students. Athlete tactics are the art of competing with an opponent. Let's designate the main factors influencing the success of an athlete's tactical actions in competitions:

- the development of such special qualities as quick reaction and quick wits;

- confident possession of an arsenal of techniques in tense competition conditions;

- possession of the skills of individual and collective tactical actions.

In coaching practice, four main stages of tactical training can be distinguished:

- development of physical, mental and intellectual qualities that underlie successful tactical actions: speed of reaction and response, observation, quick decision-making;

- improving technique, mastering individual tactical actions;

- working out individual, group and team tactical actions;

- the introduction of learned tactical techniques into the competition situation, or imitating it [1].

Mastering tactical training in various sports can be conditionally divided into two types: general training and special training. Acquiring theoretical knowledge of tactics at lectures, while observing competitions or independent study of specialized literature, students receive general tactical training. As a result of the practical application of tactics in training sessions and directly at competitions, special tactical training takes place.

I.M. Butin that the tactical skill of an athlete is based on a large stock of knowledge, skills and abilities, as well as his physical, technical, moral and volitional readiness, which allows you to accurately fulfill the plan, make the right decision to achieve victory or a high result [2].

Psychic preparation of students is of no less importance for achieving successful results in competitions. This implies a complex system of psychological and pedagogical influences that form in young athletes the personality traits and mental qualities necessary for successful performances at competitions. In the process of mental preparation, young athletes develop an attitude towards competitive activity and adaptation to extreme conditions of competition. This is due, on the one hand, to the uniqueness of the competition environment, and on the other, to the individual originality of the athlete's personality.

Without mental preparation, students cannot always resist such confusing factors as lack of confidence in their abilities, fear of possible defeat, stiffness, overexcitation, etc. Thus, the worked-out physical, technical and tactical abilities of a young athlete may not be fully realized in competition conditions.

There are two known ways of mental preparation of students for competitions. The first one teaches athletes universal methods of mental readiness for activities in extreme situations. These include: methods of control and self-regulation of emotional states, concentration of attention, self-organization and mobilization of volitional and physical efforts to the maximum. 
The second way is the development of techniques for modeling the conditions of competitive wrestling: the formation of the necessary state of the athlete's mental readiness for the upcoming competition.

Psychological preparation is necessary throughout the entire period of preparation of students for competitions: at training sessions, training camps and directly at competitions [3].

So, competition is the key formation of the sports system. Preparing young athletes studying at universities for competitions is a complex multifaceted process that implies professional training activities. In the process of preparing for sports competitions, the physical, technical, tactical, mental properties and personality traits of the student are improved and corrected, which leaves an imprint on the formation of a strong character and a healthy lifestyle of the young generation.

\section{Pedagogical conditions for preparing students for sports competitions}

From a sectoral point of view, the pedagogical conditions created to ensure the process of preparation, education and upbringing of a person for sports competitions, material support, social, pedagogical and psychological environment, the content of purposeful educational activity and it reflects the essence, unity, a set of material, didactic and technical means, ensuring the effectiveness of pedagogical activity. So, in order to achieve the goal of improving the system of training schoolchildren for sports competitions:

- material and technical support (material and technical base of general secondary education, in particular its availability for preparation for sports competitions, hall, equipment (based on video, audio and film library, computer presentations);

- environment (social and educational relations between social subjects - parents, teachers, representatives of public organizations and students);

- pedagogical activity (practical events organized by teachers, parents, media libraries (teachers, media libraries, technical staff, etc.), as well as employees of specialized public organizations to improve the system of preparing schoolchildren for sports competitions);

- materials that reveal the content of the teacher's pedagogical activity (regulatory documents, guidelines and guidelines, special literature);

- educational developments, projects, scenarios of spiritual and educational work, etc., having material (building or room with a gym or playground, equipment) didactic and educational impact (promoting the importance of improving the system of preparing students for sports competitions) and technical (equipment, mechanisms: simulator, steamer, ball, etc.) and tools used in organizing virtual (online) training.

Finding a positive solution to the research problem, solving the following problems in order to ensure the effectiveness of improving the system of preparing students for sports competitions testifies to the creation of pedagogical conditions in this regard:

1. Assessment of the material and technical support of the university.

2. Creation of a material and technical base (equipping a sports facility, building or premises at the level of existing requirements) and establishing its activities, which will improve the system of preparing students for sports competitions in the institution.

3. Make a decision on cooperation between parents, teachers, representatives of public organizations and the students themselves to improve the system of preparing students for sports competitions.

4. Determination of the content of pedagogical activities aimed at improving the system of preparing students for sports competitions and organized by teachers, parents, sports personnel (teachers, coaches, technicians, etc.), as well as employees of relevant public organizations. Justification and development of the methodology.

5. Creation of didactic and technical support for improving the system of training students for sports competitions.

6. Ensuring the effective and active functioning of a wide range of sports in higher education.

The results of the assessment of the material and technical support of the university will help determine whether there are conditions that allow to effectively form the system of preparing students for sports competitions. If in foreign countries, in many cases, there is experience in the formation of sports facilities in educational institutions on the basis of departments / faculties of physical culture as a separate part of the institution, then in some countries a sports organization is recognized as a complex with higher education.

\section{Results}

The developed methodological recommendations for improving the pedagogical conditions of preparing students for sports competitions are used in the preparation of students at the Faculty of Physical Culture, in refresher courses for teachers of physical culture, as well as in teaching pupils of children's sports schools.

The reliability of the research results is ensured by relying on clear methodological positions, theoretical analysis and generalization of the achievements of the psychological and pedagogical sciences, the use of a complex of research methods adequate to its goals, objectives and the results of a sufficient quantitative and qualitative analysis of the data of the pedagogical experiment, the work of the applicant as an NOC of the Republic of Uzbekistan. 
Approbation of the study and implementation of the results. The main theoretical provisions, conclusions and recommendations were presented by the author in reports and speeches at scientific and practical conferences, including national and foreign.

Organization of the study. In the organization of the study, taking into account the tasks to be solved, three stages can be conditionally distinguished.

At the first stage:

- the scientific literature on the research topic was studied;

- methodological approaches and initial parameters of the research were determined: goal, object, subject, hypothesis, objectives and research methods;

- substantiated the essence of the basic concepts, determined their content;

- domestic experience was analyzed and summarized on the pedagogical conditions of improving the process of preparing students for sports competitions.

At the second stage:

- a model of the process of preparing students for sports competitions was developed;

- the pedagogical conditions of its effective functioning were identified and substantiated;

- Experimental research work was carried out to study the functional state of students;

- pedagogical observation was carried out; questioning; conversations, etc.

At the third stage, the analysis of the research results was carried out, the literary design of the dissertation was carried out and the implementation of practical recommendations.

Scientific novelty of the research results:

1. A new model of the process of improving the system of preparing students for sports competitions on innovative pedagogical conditions has been developed.

2. The theoretical substantiation of the necessity of pedagogical conditions of the functional state of the human body in the educational - training process of preparing students for sports competitions is given.

3. Revealed and substantiated pedagogical conditions for improving the process of preparing students for sports competitions.

The theoretical significance of the research lies in the fact that its results complement the theory and methodology of vocational education and introduce new elements into existing research in the field of using diagnostic methods for assessing the functional state of the human body, it substantiates the need to improve the pedagogical conditions of preparing students for sports competitions.

\section{Conclusion}

The conducted dissertation research led to the following conclusions:

1. Consideration of the process of preparing students for sports competitions as a pedagogical problem has shown that throughout all stages of the formation and development of our society, improving the activities of its social institutions (family, educational institutions, governing bodies, the public, etc.) to improve physical development, strengthening and preserving the health of the younger generations, forming their need for a healthy lifestyle, etc. one way or another, it was posed and decided. This problem is especially urgent at the present time, in the conditions of the country's transition to market relations.

2. In the context of modernization of the education system, including professional education, the role of educational institutions that train specialists in the field of physical culture and sports is increasing. In order to improve the pedagogical conditions for preparing students for sports competitions, it is necessary to develop and implement a model in the educational process of the university, which includes the goal, objectives, principles, work content, stages of readiness formation, forms, methods and means of organizing the educational process.

3. An important means of improving the pedagogical conditions of preparing students for sports competitions is the use of methods of gamification and simulation of students of the Faculty of Physical Education.

4. The creation of the following pedagogical conditions contributes to an increase in the level of preparedness of graduates of physical culture faculties for sports competitions in modern conditions:

- formation of students of the Faculty of Physical Culture of understanding the need to use appropriate methods of diagnostics of the functional state for participation in competitions;

- equipping students with relevant knowledge about the methods of diagnosing the functional state, in particular psychophysiological methods, about the methods of their use, as well as the ability to apply them in the educational and training process;

- widespread use of modern technical teaching aids in the process of diagnosing the functional state of training students for sports competitions;

- preparation of teachers of special disciplines for the use of psychophysiological methods for diagnosing the functional state of the body in the process of preparing students for sports competitions.

Our research has resolved the set tasks within the framework of a specific topic and scientific problem.

On the basis of experimental work, we objectively developed, tested and introduced into the practice of teachers of special disciplines a model of preparing students for sports competitions on modern pedagogical conditions. 


\section{References:}

1. Abdalina L.V., Frolova O.S. (2017). Innovatsionnayakompetentsiyapedagoga: usloviyaformirovaniya v protsessevnutrishkol'nogopovysheniyakvalifikatsii. Izvestiya VGPU. 117(4). URL: https://cyberleninka.ru/article/n/innovatsionnaya-kompetentsiya-pedagoga-usloviya-formirovaniya-Vprotsesse-vnutrishkolnogo-povysheniya-kvalifikatsii.

2. Abramova V.V. Formirovanieprofessional'noikompetentnostibudushchikhuchiteleifizicheskoikul'tury.

(2006). Avtoreferatdissertatsiikandidataped.nauk, Rossiya, 27 p.

3. Bagautdinov Z.M. (2015). Razvitieprofessional'noikompetentnostiuchitelyafizicheskoikul'tury. VestnikYuzhno-Ural'skogogosudarstvennogogumanitarno-pedagogicheskogouniversiteta, (8), 13-17. URL: https://cyberleninka.ru/article/n/razvitie-professionalnoy-kompetentnosti-uchitelya-fizicheskoykultury.

4. Butin I.M. (2000).Lyzhnyi sport: uchebn. posobiedlya stud. vysshikhuchebn. zavedenii. - M.: Akademiya, $123 \mathrm{p}$.

5. Il'ina N.F. (2014). Stanovlenieinnovatsionnoikompetentnostipedagoga $\quad$ v regional'nomprostranstvenepreryvnogoobrazovaniya: dis. ... kand. ped. nauk. Krasnoyarsk.

6. Isyanov, R., Rustamov, K., Rustamova, N., \&Sharifhodjaeva, H. (2020). Formation of ICT competence of future teachers in the classes of general physics. JournalofCriticalReviews, 7(5), 235-239. doi:10.31838/jcr.07.05.41.

7. Kal'kovaG.V.

Sovershenstvovanieprotsessapovysheniyakvalifikatsiipedagogicheskikhkadrovsrednegoprofessional'nog oobrazovaniya: av-toref. dis. ... kand. ped. nauk. Moskva.

8. KholodovZh.K. (2000). Teoriyaimetodikafizicheskogovospitaniyaisporta: uchebn. posobie. - M.: Akademiya, $200 \mathrm{p}$.

9. Kodzhaspirova G.M., KodzhaspirovA.Ju. (2000). Pedagogicheskijslovar: dlja stud. vyssh. isred. ped. ucheb. zavedenij. M.: Akademija.

10. Korshunova, O. S. (2015). Formirovaniekompetentsii po fizicheskomuvospitaniyu v vuze s uchetomprofessiogrammybudushchikh. Molodoiuchenyi. 95(15):637-640. URL: https://moluch.ru/archive/95/21322/.

11. Lavitskaya, E.

S.

(2014). Teoreticheskoeobosnovanieinnovatsionnogosoderzhaniyaprofessional'noipodgotovkistudentovfizkul'tur nogoprofilyanazanyatiyakh po sportivnymigram. Molodoiuchenyi. 77(18):91-94. URL: https://moluch.ru/archive/77/13138/.

12. Lavitskaya, E. S. Osobennostiformirovaniyaprofessional'noikompetentnostistudentovfizkul'turnogoprofilyanazanyatiyakh po sportivnymigram. Molodoiuchenyi. 91(11): 600-604. URL: https://moluch.ru/archive/91/19777/

13. Litvintseva I.G. Prakticheskoeobucheniekakfaktorformirovaniyaprofessional'noikompetentnostibudushchikhuchiteleifizi cheskoikul'tury. Avtoreferatdissertatsiikandidataped.nauk, Ulan-Ude, 26 p.

14. Makarov, P. A. Formirovanieproforientatsionnoikompetentnostibudushchegouchitelyafizicheskoikul'tury. Avtoreferatdissertatsiikandidataped.nauk, Samara, $26 \mathrm{p}$.

15. Moskvitina, L.N. Formirovanieprofessional'noikompetentnostiuchitelyaobshcheobrazovatel'noishkoly sistemedopolnitel'nogoprofessional'nogoobrazovaniya: dissertatsiya ... kandidatapedagogicheskikhnauk: 13.00.08, Moskva, $246 \mathrm{p}$.

16. Nikiforov, N. V. (2009). Formirovanieprofessional'noikompetentnostibudushchikhpedagogov-trenerov po vol'noibor'be. Avtoreferatdissertatsiikandidataped.nauk, Yakutsk, 26 p.

17. Rakhimov, B. K., Misirova, N. T., Norboeva, S. M., Toshmatova, M. D., \&Turdieva, R. K. (2020). Educating research approach in future teachers. Journal of Critical Reviews, 7(4), 62-67. doi:10.31838/jcr.07.04.13.

18. Rakhimov, B., Umarov, H., Rasulova, Z., Mamarahimov, S., \&Abdurasulova, S. (2020). Formation of social competence of primary school children by means of educational subjects. JournalofCriticalReviews, 7(5), 240-242. doi:10.31838/jcr.07.05.42

19. Rustamova, N. R. (2020). Development of technology based on vitagenic experience using media resources in higher educational institutions students teaching. International Journal of Scientific and Technology Research, 9(4), 2258-2262. Retrieved from www.scopus.com

20. Rustamova, N. R. (2020). Training of students of cognitive processes based on vitagen educational situations. International Journal of Advanced Science and Technology, 29(8 Special Issue), 869-872. Retrieved from www.scopus.com

21. Senko Yu.V. (2000). Gumanitarnyeosnovypedagogicheskogoobrazovaniya: Kurslektsii: Uchebnoeposobiedlya stud. vyssh. ucheb. zavedenii. M.: Izdatel'skiitsentr «Akademiya», 240p. 
22. ShkerinaL.V.

Razvitieinnovatsionnoipedagogicheskoikompetentnostistudentovpedagogicheskogovuzakakfaktorikhpr ofessional'noiuspeshnosti.

URL: http://www.kspu.ru/doccom/c2.data/12efb66ff585e6aed0489c2641a6c9e9.doc.

23. Strategiyamodernizatsiisoderzhaniyaobshchegoobrazovaniya: materialydlyarazrabotkidokumentov po obnovleniyuobshchegoobrazovaniya. (2001). M.: NFPK.

24. Tikhomirov, Yu. V., \&Pravdov, M. A. (2015). Model' formirovaniyaprofessional'noikompetentnosti u budushchikhuchiteleifizicheskoikul'turynaosnovesovershenstvovaniyametodikiprepodavaniyabazovykhi novykhvidovfizkul'turno-sportivnoideyatel'nosti. Russian Journal of Education and Psychology, 47(3): 164-172.

25. Verevkina S.V., Sapegina T.A., (2019). Osobennostipodgotovkistudentov $\mathrm{k}$ sportivnymsorevnovaniyam. Retrieved from: https://elar.rsvpu.ru/bitstream/123456789/30960/1/fksz_2019_013.pdf.

26. NurmagomedovaEl'miraNurmagomedovna. $\quad$ (2015). $\quad$ Sportivnyesorevnovaniya $\quad \mathrm{V}$ pedagogicheskomvuzekaksredstvoimetodobshcheifizicheskoi, professional'no-prikladnoi, sportivnoipodgotovkiikontrol' ikheffektivnosti. Pedagogicheskienauki, 38(1): 1-11.

27. Yunusova, D. M., Ilhamova, I. N., Daulanova, K. I., Rustamova, N. R., \&Normuradova, G. M. (2020). Using of interactive educational technologies in teaching medical terms. Journal of Advanced Research in Dynamical and Control Systems, 12(6 Special Issue), 596-601. doi:10.5373/JARDCS/V12SP6/SP20201068.

28. Zvyagintseva, N. Yu. (2009). Formirovanieinnovatsionnoikompetentnostibudushchegopedagoga. VestnikAdygeiskogogosudarstvennogouniversiteta. Seriya 3: Pedagogikaipsikhologiya, (4), 47-51.

29. Bal'sevich, V.K. (2003). Sportivnoorientirovannoefizicheskoevospitanie: obrazovatel'nyiisotsial'nyiaspekty. Teoriya i praktikafizicheskoikul'tury. (5): 19-22.

30. Panachev, V.D. (2011). Fizicheskayakul'tura i sport - sredstvosotsial'nopedagogicheskogorazvitiyalichnosti. Monitoringkachestvazdorov'ya v praktikeformirovaniyabezopasnoizdorov'esberegayushcheiobrazovatel'noisredy: materialyvseros. nauch. prakt. konf., g. Volgograd, 25-27. pp. 28-32.

31. Treshcheva, O.L. (2003). $\quad$ Formirovaniekul'turyzdorov'yalichnosti $\quad$ v obrazovatel'noisistemefizicheskogovospitaniya [Tekst]: avtoref. dis... doktoraped. nauk. Omsk, 38 p. 